\title{
KANSALAIS- JA KANSANOPISTOT MUUTOSTEN EDESSÄ
}

\begin{abstract}
Aikuiskoulutuksen veteraanit, 100-vuotias kansanopistoliike sekä 90-vuotias kansalais- ja työväenopistoliike uudistuvat. Tärkeimpiä ovat ne muutokset, jotka tapahtuvat opetuksen sisällössä, työskentelytavoissa ja välineissä - ajan seuraaminen opiskelijoiden opettajien tasolla. Mutta myös säädöstasolla on tapahtumassa olennaisia muutoksia, joilla on yhteys ammatillisen aikuiskoulutuksen ja julkishallinnon kehittymiseen. Näiden mm. opetusministeriön opistolakityöryhmän (1989:50) esittämien muutosten on pelätty muuttavan vapaan sivistystyön merkitystä välineelliseen hyötytavoitteiseen suuntaan.
\end{abstract}

\section{Opistolakeihin muutoksia}

Opetusministeriö käsittelee parhaillaan kansalais- ja työväenopistojen, kansanopistojen ja iltalukioiden lainsäädäntöä pohtineen aikamme henkeä ilmentävän opistolakityöryhmän esitystä. Toimeksiantonsa mukaisesti työryhmä on mm. selvittänyt mainittujen työmuotojen osalta, miten opistot voivat (halutessaan) huolehtia ammatillisen aikuiskoulutuksen tehtävistä valtioneuvoston rahoitusperiaatepäätökset huomioiden. Mittavin työryhmän eteen asetettu kysymys oli kuitenkin esityksen laatiminen laskennallisiin perusteisiin rakentuvasta kansalais- ja työväenopistojen valtionapujärjestelmästä. Tehtävänä oli etsiä malli menoperusteisesta rahoituksesta suoritepohjaan siirtymiselle.

\section{Kansalaisopistolain olennaisimmat muutosesitykset}

Työryhmä esittää vuodelta 1962 peräisin olevan ja moneen kertaan muutetun kansalais- ja työväenopistolain kokonaisuudistusta. Esitetyn uuden kansalaisopistolain idean mukaan opistojen päätehtävä olisi edelleen antaa yleissivistävää aikuiskoulutusta. Valtionosuusjärjestelmä esitetään uudistettavaksi niin, että menoperusteisen $70 \%$ mukaan maksettavan valtionosuuden järjestelmästä siirrytään laskennalliseen kuntien kantokykyluokituksen mukaiseen valtionosuuteen. Valtionosuusasteikko olisi sama kuin koulutoimessa. Laskentayksiköksi esitetään opetustuntia ja valtionosuus määräytyisi opetustuntia kohti - laskettujen todennäköisten keskimääräisten kustannusten perusteella. Alueellisten erojen tasoittamiseksi opetustunnin hinta on esitetty porrastettavaksi opiston sijaintikunnan mukaan, asutusrakenneryhmittäin. Työryhmä esitti ajatuksensa ennen selvitysmies Hiltusen valtioapumallin julkistamista ja asettui kannattamaan sellaista mallia, jossa valtionosuus on sidoksissa opiston toimintaan. Opetusryhmän minimikokoa tai tuntikehystä koskevaa säätelyä työryhmä ei esittänyt.

\section{Kansalaisopistojen perustehtävä säilyy}

Kansalaisopistoille halutaan antaa mahdollisuus yleissivistävän päätehtävän ohella paikallisten tarpeiden ja päätösten mukaista ammatillista aikuiskoulutusta. Samoin opis- 
tojen tehtäväkenttään halutaan sisällyttää aikuiskoulutusajattelusta huolimatta mahdollisuus taiteen perusopetuksen antamiseen lapsille ja nuorille.

Valtioneuvoston ammatillista aikuiskoulutusta koskevan rahoitusperiaatepäätösten mukaisesti esitetään työnantajan henkilöstölleen tilaaman koulutuksen kustannukset työnantajan kokonaan maksettaviksi. Sama koskee työvoimahallinnon mahdollisesti kansalaisopistoilta ostamaa koulutusta.

Omaehtoisen ammatillisen (lyhytkestoisen) koulutuksen rahoitus esitetään ratkaistavaksi siten, että koulutuksen maksavat valtio ja koulutukseen osallistuvat opiskelijat yhdessä. Valtionosuus määräytyisi esitetyssä mallissa kuten yleissivistäviin opintoihin saatava tuki. Opiskelijoiden rahoitus koostuisi kurssimaksuista. Kansalaisopistoihin hakeutuu omaehtoiseen koulutukseen ihmisiä sekä yleissivistävin että ammatillisin tavoittein. Koulutukseen hakeutuvien motiivien kysely, opiskelijoiden erottelu motiivien nojalla ja erilainen kohtelu johtaisi keinotekoisuuteen ja edellyttäisi vain lisää hallinnollisia toimenpiteitä.

Pääpaino 278 opiston n. 2,1 miljoonaa tuntia kattavassa opetuksessa ja runsaat 600000 kansalaista tavoittavassa opetuksessa säilyy jatkossa yleissivistävillä aineilla.

\section{Muita kansalaisopisto- lain muutoksia}

Valtionosuusjärjestelmän lisäksi esitetään uudistettavaksi opistojen toimintaa ja hallintoa koskevat säännökset. Nykyisestä alistusja lupamenettelystä luovuttaisiin pitkälle. Kansalais- ja työväenopistonimityksen sijasta yläkäsitteenä ryhdyttäisiin käyttämään yksinkertaisesti nimitystä kansalaisopisto.

Työkauden vähimmäispituus nousisi nykyisestä 26 viikosta 33 viikkoon. Opetushenkilökunnan osalta esitetään muutoksena aikaisempaan lehtorin virkojen perustamismahdollisuutta ja opistojen henkilöstön täydennyskoulutuksen saattamista valtionapuun oikeuttavien menojen piiriin. Kokeilutoimintaa halutaan helpottaa ja opistojen perustamiskustannuksissa esitetään vuokra-arvojärjestelmästä luopumista.

\section{Kansanopistolain olennaisimmat muutokset}

Vuonna 1985 kokonaan uusittuun, osittain suoriteperusteiseksi säädettyyn ja 1988 hallinnollisesti kevennettyyn kansanopistolakiin työryhmä esitti eräitä parannusehdotuksia.

Kansanopistolaki sallii jo nykyisin ammatillisen perus- ja lisäkoulutuksen järjestämisen ja tätä koulutusta myös annetaan opistoissa. Peruskoulutus on järjestetty ammatillista koulutusta koskevien kehittämisohjelmien mukaisena, $3-4$ vuotta kestävänä koulutuksena, jonka piirissä vuosittain opiskelee noin 1500 opiskelijaa. Ammatillinen henkilöstökoulutuksen luonteinen lisäkoulutus on käytännössä tarkoittanut täydennyskoulutuskursseja, joille työvuonna 1987/88 kouluhallituksen tekemän selvityksen mukaan osallistui noin 2400 osanottajaa eli vain muutama prosentti kurssiopiskelijoista.

Kansanopistolakia esitetään - kuten kansalaisopistolakiakin - tarkistettavaksi ammatillisen (henkilöstö, työllisyys ja omaehtoisen) koulutuksen osalta valtioneuvoston rahoitusperiaatepäätöksiä vastaavaksi. Samalla esitetään eräitä muita pienempiä vapaan sivistystyön työmuotojen välisiä raja-aitoja vähentäviä ja aikuisväestön koulutukseen hakeutumista helpottavia muutoksia.

Kurssitoiminta

käytännössä kaksipäiväiseksi

Olennaisesti koulutukseen hakeutumista helpottaa valtionavun alla järjestettävien kurssien vähimmäispituuden muuttaminen kolmesta vuorokaudesta 15 tuntiin. Varsin yleinen käytäntö on ollut, että esim. viikonloppukurssin ensimmäinen päivä on supistunut lyhyeen esittäytymiseen ja orientaatioon tehokkaan opiskelun supistuessa kahteen päivään. Nyt kurssien järjestäminen muuttunee joustavammaksi sekä osallistujia että opistoja ajatellen.

\section{Muita kansanopisto- lain muutoksia}

Kansanopistojen palveluksessa olevan henkilöstön täydennyskoulutusta ja opistojen kokeilutoimintaa koskevat säädökset esitetään muutettaviksi uutta kansalaisopistolakia vastaaviksi. Hallinnollista päätösvaltaa siirretään alaspäin esimerkiksi siirtämällä eräät opetuksen ja opiskelijaviikkojen määrää koskevat kysymykset opetusministeriöltä kouluhallituksen ratkaistavaksi.

Osan valtionavustaan opistot ovat saaneet tuotantonsa, opiskelijaviikkojen määrästä riippuen. Etukäteen vuosittain määrättävää 
opiskelijaviikon yksikköhintaa ei ole voimassa olevan lain mukaan ollut mahdollista myöhemmin tarkistaa. Nyt työryhmä esittää opistojen suoriteperusteiseen valtionapumekanismiin lisättäväksi kustannustason muutosten varalta tarkistusmahdollisuuden.

Perustamiskustannusten valtionosuusjärjestelmään työryhmä ei esittänyt muutoksia.

Maassa toimivan 93 kansanopiston toiminta tulee uudistusten jälkeen edelleenkin ensisijaisesti painottumaan yleissivistävän aikuiskoulutuksen suuntaan. Ilmeistä kuitenkin on, että kurssiopiskelijoiden määrä jatkaa kasvuaan nykyisestä 64000 vuotuisesta opiskelijasta.

\section{Uudistusaikataulu}

Aikaisintaan muutosten voidaan olettaa astuvan voimaan vuonna 1991. Toisaalta ammatillisia aikuiskoulutuskeskuksia koskevat muutokset edellyttävät tiettyä muutosvauhtia myös yleissivistävän aikuiskoulutuksen taholla.
Opistolakityöryhmän asettamisen aikoihin käyty voimakaskin keskustelu aikuiskoulutuksen ammatillistumisen myötä esiinnousevista hyötytavoitteisuuden vaaroista ei juurikaan heijastunut työryhmän työskentelyyn. Vaikka tiettyä koulutuksen välineellistämisen makua ei opistolakityöryhmän työssä voikaan kiistää, ovat esitetyt muutokset opistojen vapausasteiden määrää lisääviä. Koulutuksen suuntaamista koskevat oppilaitosten valintamahdollisuudet ovat lisääntymässä. Nähtäväksi jää, vinouttavatko valtionavun ulkopuolella tapahtuvan toiminnan laajentamisen mahdollisuudet opistojen tarjontaa yleissivistäviä koulutuspalveluja heikentävään suuntaan ja tuoko jo käytännössä alkanut tuotanto- ja liike-elämän lähestyminen uutta kosketusta todellisuuteen.

\section{HEIKKI SEDERLÖF}

